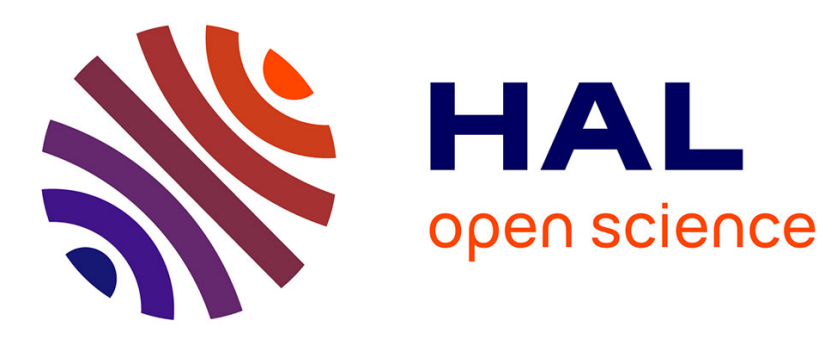

\title{
Toward a comparative typology of 'eating' in Kanak languages
}

Anne-Laure Dotte, Claire Moyse-Faurie

\section{To cite this version:}

Anne-Laure Dotte, Claire Moyse-Faurie. Toward a comparative typology of 'eating' in Kanak languages. Oceanic Linguistics, 2021, 60 (1), 10.1353/ol.2021.0006 . hal-03094721v2

\section{HAL Id: hal-03094721 \\ https://hal.science/hal-03094721v2}

Submitted on 26 Jul 2021 (v2), last revised 15 Apr 2022 (v3)

HAL is a multi-disciplinary open access archive for the deposit and dissemination of scientific research documents, whether they are published or not. The documents may come from teaching and research institutions in France or abroad, or from public or private research centers.
L'archive ouverte pluridisciplinaire HAL, est destinée au dépôt et à la diffusion de documents scientifiques de niveau recherche, publiés ou non, émanant des établissements d'enseignement et de recherche français ou étrangers, des laboratoires publics ou privés. 


\title{
Toward a Comparative Typology of 'Eating' in Kanak Languages
}

\author{
Anne-Laure Dotte ${ }^{\dagger}$ and Claire Moyse-Faurie \\ †UNIVERSITÉ DE LA NOUVELLE-CALÉDONIE AND *LACITO-CNRS
}

\begin{abstract}
This paper aims to explore the diversity of expressions for food ingestion in some Oceanic languages, and intends to map out the convergences and divergences attested among these languages. Six main points are addressed: first, a brief historical and environmental survey will be presented; second, the parameters distinguishing 'eat' verbs among the Kanak languages will be compared with the differentiation made in other Oceanic languages. In the notional domain under discussion, each Kanak language has its own food noun categories, depending on physical, nutritive or symbolic (cultural) criteria, and distinguished on the basis of the verb they combine with. Third, a typological perspective will show how Kanak languages are organized with respect to the contextual aspects incorporated into the meaning that is expressed together with the basic action of eating. Then, we will discuss some frequent distinctions found in Oceanic languages to extend the comparison. Fifth, the role of possessive classifiers reserved for specific kinds of food nouns and their relation to different 'eat' verbs will be investigated; and finally, some remarks will be made on the diversity of constructions available for 'eat' verbs in Oceanic languages.
\end{abstract}

Keywords: Kanak/New Caledonian languages, Polynesian languages, comparative lexicology, eating verbs, food categories, possessive classifiers, transitivity

1. INTRODUCTION. ${ }^{1}$ The semantic domain of food, and more precisely of the action of food (and drink) ingestion, has been of interest in various subfields of linguistics: typology (Newman 2009), syntax (Næss 2011), semantics (Wierzbicka 2009), and historical comparison (Lichtenberk 1994). All of these studies address the fact that eating and drinking are vital needs and universal activities but are not uniformly categorized and expressed in the world's languages:

When one studies the closest counterparts of the English concept 'eat' and 'drink' in many different languages, in many different geographical and cultural areas, one discovers that there are really many different ways in which the "bodily intake of substances" can be conceptualized and categorized. The familiar English, and more generally, European division between 'eating' and 'drinking' is by no means the only one. If we try to interpret the conceptualizations reflected in other languages through the prism of this one, we will be imposing on them an Anglocentric, or Eurocentric, perspective. (Wierzbicka 2009:66)

In section 2, through a brief historical survey, we will first have a look at the etyma that have been reconstructed in Proto-Oceanic (POC) (section 2.1) for the eating verbs, as well as the reflexes now found in Oceanic languages (section 2.2). Then we will briefly present the relevant distinctions in Kanak languages and describe to what extent they reflect the POC reconstructions (section 2.3), ${ }^{2}$ pointing out which differentiations already existed in POC, and which innovations took place in the new environment, as new kinds of food became available when the Austronesians reached New Caledonia. In section 3, we will more specifically examine the Kanak languages through a comparative survey of the different 'eat' verbs, their restrictions and the contextual features incorporated in them. A more detailed characterization of the relevant subsystems in Kanak languages will then be carried out (section 4), extending the comparative perspective to other Oceanic languages and to European and other languages. A brief sketch of cross-linguistic observations in section 4.1 will be used to shed additional light on the specifics of Kanak languages, which will then be further characterized in their genealogical and areal specifics through a detailed comparison with other Oceanic languages (section 4.2). The case of Kanak languages with possessive classifiers reserved for specific kinds of food nouns will be described in section 5.1, and the semantic features and restrictions of these possessive classifiers will be compared with the ones described earlier for the 'eat' verbs (section 5.2).

In section 6, we will discuss the morphosyntactic characteristics of the 'eat' verbs in Kanak languages from a cross-linguistic perspective (Newman 2009). It will be shown that they do not behave like ordinary transitive verbs (Næss 2011), occurring in different types of constructions and showing selectional restrictions on the patient (Gast et al. 2014). Our conclusion (section 7) will summarize the main findings characterizing the Oceanic "world of nutrition and eating", and more specifically, the New Caledonian data.

We will leave aside many other aspects concerning the fundamental human act of eating: nouns for food, all kinds of verbs expressing the manner of eating, the quantity ingested, or the social behavior. According to Ross

1. We are very grateful to the two anonymous referees for their careful reading and thoughtful comments towards improving our paper. We also would like to thank Ekkehard König and Yuko Otsuka for their valuable suggestions.

Non standard abbreviations (those not in The Leipzig Glossing Rules) are: AGT, agent marker; DEIC, deictic; N, noun; P_CL, possessive classifier; RESTR, restrictive particle; SPC, specific article; SUF, suffixed form.

2. "Kanak" has become the usual and politically correct term to designate the autochtonous inhabitants of New Caledonia and their vernacular languages. More information on these languages can be found on the Académie des Langues Kanak website (http://www.alk.nc). 
(2008:36-37): "People in traditional Oceanic-speaking villages ate one cooked meal a day, usually after the day's work. The meal typically consisted of starchy staples, made more appetising by the addition of coconut milk, leafy vegetables and sometimes some meat or fish." Food preparation has been well described by Lichtenberk (1994) and his article would be an excellent starting point for further investigations of food preparation in specific Oceanic languages. The drinking domain (understood as "the ingestion of liquid nutrient") will only be mentioned in its relation to the eating domain (section 4.2) and would deserve a much more detailed investigation on its own.

\section{THE VERB 'EAT' IN OCEANIC LANGUAGES.}

2.1 HISTORICAL CONSIDERATIONS. The Oceanic subgroup (a subgroup of Eastern Malayo-Polynesian, which in turn is a subgroup of Malayo-Polynesian, a first-order subgroup of Proto Austronesian) is the largest and very well defined subgroup of the large Austronesian language family. It includes around 500 languages, spoken along the coasts of Papua New Guinea, in the nearby and remote Melanesian islands (the Bismarck archipelago, Bougainville, Solomon Islands, Vanuatu, New Caledonia, and Fiji), in Micronesia (except for Chamorro and Palau, both belonging to the Western Malayo-Polynesian group), and in Polynesia, as far as Hawai'i and Rapanui (Pawley and Green 1984; Blust 2009).

Oceanic speech communities vary enormously in their size, from Fijian (with over 300,000 speakers) or Samoan (with more than 250,000 speakers) to an average size of 4,000 speakers in Papua New Guinea and the Solomon Islands, 2,000 in New Caledonia, and about 1,500 in Vanuatu. A number of these languages are moribund, each with fewer than ten speakers according to the latest available census data. We can roughly distinguish between a Melanesian multilingual archipelago on the one hand, and monolingual Micronesian and Polynesian islands, on the other. It is indeed in Melanesia that we find the highest linguistic densities in the world, as for example in Vanuatu, with more than a hundred languages for 285,359 inhabitants (2018 census). ${ }^{3}$

The first settlers in Remote Oceania (Temotu Province in the Solomon, Vanuatu, New Caledonia, Fiji, Polynesia, and Micronesia) introduced domesticated plants (banana, taro, sugarcane, yam, etc.) as well as dogs, pigs and chickens. The history of cultivated plants and domesticated animals in Oceania is well documented (Blust 2017). It deserves special mention that neither dogs nor pigs were originally introduced or survived in New Caledonia before the contact with Europeans. ${ }^{4}$ The only land mammals existing in New Caledonia were white rats and flying foxes (fruit bats). Consequently, the main protein sources available for the Kanak people were birds and fish. There is no doubt, on the other hand, that the Kanak settlers arrived with tubers, fruits and tree crops and practiced horticulture right from the start, as the early Lapita sites found in Remote Oceania attest (Kirch 2000:109; Pawley 2017:294). ${ }^{5}$ Horticulture and fishing were the main food resources and it is not surprising that the diversity we found in 'eat' verbs are mainly based on these activities.

We will now look at the reconstructed terms for 'eat' found in the main Austronesian subgroups to which the Kanak languages belong. In Proto Malayo-Polynesian (PMP) as well as in POC, a pair of verb forms are reconstructed for the general meaning 'eat', one intransitive and the other transitive:

(1) PMP *payan *kaen-i

POC *payan *kani

INTR TR

PMP *panan 'eat (INTR)' is derived from the root *kaen 'eat' by affixation of the intransitive prefix *paN- while PMP transitive *kaen- $i$ includes the location undergoer voice suffix *-i (which became the POC transitive suffix $*_{-i}$ ) (Ross et al. 2016:224). ${ }^{6}$

2.2 'EAT' VERBS IN OCEANIC LANGUAGES. In many Oceanic languages, *kani has replaced *payan, but some languages still make a distinction between 'eat (TR)' and 'eat (INTR)', such as Ramoaaina (MesoMelanesian): an 'eat (TR)' < POC *kani and wayan 'eat (INTR)' < POC *panan; this is also the case in several Southeast Solomonic languages, such as Toqabaqita: qani 'eat (TR)' < POC *kani versus fana 'eat (INTR)' < POC * payan and in some South Vanuatu languages, or with a causative meaning (North Central Vanuatu and Polynesian subgroups), as East Futunan fāgai 'feed s.o.'. As we will see, it is also the case in Iaai, a Kanak language spoken in Ouvéa (Loyalty Islands).

POC *payan (INTR) and *kani (TR) probably both meant 'eat (in general)' and 'eat starchy food', including yams, taro and other root crops, cooking bananas and breadfruit.

As mentioned by Ross (2008:39-41), "In Oceanic languages for which there is detailed information about verbs of eating, there is usually at least one other 'eat' verb, with the meaning 'eat starch and protein food together'. Sometimes there is also a verb meaning 'eat meat', 'eat fish' or 'eat protein food'."

3. https://www.populationdata.net/pays/vanuatu/

4. The first dog, named Rhin, arrived in New Caledonia in 1845 (Haudricourt and Dibie 1987:140).

5. The Lapita people moved from South-East Asia three thousand years ago on big canoes to settle in the majority of the previously uninhabited Melanesian and Polynesian islands. The most significant vestige of their settlement remains the finely decorated potteries found in the Bismarck Archipelago, New Caledonia, Vanuatu, Fiji, Samoa and Wallis-et-Futuna. Lapita is then the word used to refer to a specific type of pottery with elaborated decoration, a cultural complex and, by extension, a migratory movement and period (Noury and Galipaud 2011).

6. The prefix * paN- marks the intransitive form of the verb; -N- combines with the root-initial consonant to produce a nasal consonant (Ross et al. 2016:224). 
Ross (2008:39) observes there are up to five different verbs of eating in Oceanic languages meanings depending on the food ingested:

1. 'eat starchy food; eat (generic)' (all languages): POC *kani and *panan

2. 'eat food consisting of starch and additional ingredients (coconut milk, leafy vegetables, fish or meat)': POC *tamaji; reflexes are found in a few languages: Mapos Buang (North New Guinea), Sursurunga (Meso-Melanesian), Arosi (Southeast Solomon), and Wayan (Fijian)

3. 'eat (sth.) as an addition to starch': Sursurunga (Meso-Melanesian), Anejom and Sye (South Vanuatu), Kosrean (Nuclear Micronesian), Wayan (Fijian) and Polynesian languages

4. 'eat fish or meat without starch', "possibly already lexicalised in POC, as *[q,k]oda(q). More usually the reflexes mean 'eat s.th. raw'" (Ross et al. 2016:231)

5. 'eat greens alone': Ramoaaina (Meso-Melanesian) and Arosi (Southeast Solomon)

Since Ross et al. (2016:229) only give three New Caledonian reflexes for all the 'eat' terms in their study (VohKoné dialects cani 'eat starchy food', Xârâcùù $k \hat{e}$ 'eat starchy food' and Iaai han 'eat'), our article will inyestigate if a larger set of Kanak languages offer similar data. Indeed, most New Caledonian languages have a specific verb for each of these five categories, but - as we will show - quite a lot of variation is identified, we will try to sort out if the lexical distinctions are either inherited from POC or specific to New Caledonian languages, and if they are due to local innovations or language contact.

2.3 THE NEW CALEDONIAN/KANAK LANGUAGES. New Caledonia is a home to twenty-eight Kanak languages plus dialects, ${ }^{7}$ greatly differing from one another and each showing high phonological complexity. All the Kanak languages belong to the New Caledonia linguistic subgroup (Haudricourt 1971; Ozanne-Rivierre 1992), except West Uvean (Fagauvea), which is a Polynesian outlier (see Moyse-Faurie et al. 2012 for a general presentation). The New Caledonia subgroup divides into three lower subgroups: North Mainland, South Mainland and Loyalty Islands. The linguistic diversity in New Caledonia is mainly due to sociolinguistic factors: before the arrival of the Europeans, there was no dominant Kanak language. Contact between small neighboring communities, practicing "egalitarian multilingualism" (the plurilinguisme égalitaire described by Haudricourt, 1961:8-9) accentuated the diachronic enriching tendencies.

In addition to the indigenous Kanak languages, New Caledonia is home to one small-scale creole, Tayo (Ehrhart 2012), French as the dominant and vehicular language, and dozens of other Indo-European, Austro-Asiatic, Japonic, and Austronesian languages brought in by migrations during the last century.

Our study is mainly based on Kanak languages for which we found sufficient reliable data for our topic. It relies on authentic data collected through our own fieldwork, complemented by vocabulary found in the available dictionaries, descriptive grammars and colleagues' first-hand data (see Table 1 for references and sources for each language).

\section{$\langle$ table 1$\rangle$}

$<\operatorname{map} 1>$

Table 2 recaps the reflexes of the POC generic term for 'eating', sometimes also used for the action of eating starchy food. Usually, it is the term for 'eating starchy food' (Mainland Kanak languages) or the general term for 'eating' and for 'eating starchy food' (Loyalty Islands languages) which reflects POC *kani 'to eat' (Pawley, in Greenhill et al. 2008).

$<$ table 2>

Some of the Mainland languages, however, have a non-related term for 'eating (in general)', such as Jawe and Caac huu; Vamale xhwi-aman; Ajië ara; Xârâcùù da; Haméa harra; Drubéa kèrè-re, etc.

\section{SEMANTIC DIFFERENTIATION OF VERBS OF EATING IN KANAK LANGUAGES. The POC} differentiation of verbs of eating, depending on the type of food ingested, is widely attested in the Kanak languages subgroup.

3.1 CANONICAL DISTINCTIONS. The lexical field of expressions for ingesting food does not relate to a homogeneous or consistent domain in Kanak languages. Two main groups are distinguished and manifest an areal distribution: the languages of Mainland New Caledonia usually differentiate several categories of food with several terms for the verb 'eat' - one general term plus up to six other terms depending on the type of food ingested. The languages of the Loyalty Islands, by contrast, do not distinguish 'eating starchy food' nor 'eating fruits' and use the general verb in these cases.

For the Mainland subgroup, the most common pattern is based on four verbs, as illustrated here by Xârâcùu as in example (2): one generic term for 'eating', and additional specific verbs, depending on what is eaten: (i) starchy food (including 'bread'); (ii) protein, flesh (including coconut flesh) and food coming from animals (meat, fish, egg, etc.); (iii) sugarcane and fruits that have to be chewed, or sucked, without being swallowed. 
(2) XÂRÂCÙÙ (Mainland)

$d a \quad$ 'eat' (general term, also used for some fruits and leafy vegetable)

$k \hat{e} \quad$ 'eat starch food' (yam, taro, sweet potatoes, rice, banana, manioc...)

xwè 'eat meat, fish, coconut or other fruit flesh'

$x w i i$ 'eat sugarcane, orange and all other fruits that are only sucked'

For the Loyalty Islands languages, the common distinction is three-way: the generic 'eat' verb plus two specific verbs for, either, the ingestion of proteins; food that has to be chewed (barks or chewing-gum ${ }^{8}$ ) or food that has to be gnawed (sugarcane). This is exemplified by the three Loyalty Islands languages Iaai, Drehu and Nengone in the following examples:

(3) IAAI (Ouvéa island)

an 'eat (generic, TR)'

hwii 'eat (or gnaw) sugarcane'

hicâ 'eat chewable food (barks, chewing-gum...)"

(4) DREHU (Lifou island)

xen 'eat (generic; anything other than protein)'

öni 'eat protein (meat, fish, egg...)'

atra 'eat (or gnaw) sugarcane'

(5) Nengone (Maré island)

$k a k a(n) \quad$ 'eat (generic; anything other than protein)'

ia 'eat protein (meat, fish, egg, seafood...)'

chaphan 'eat chewable barks (magnania, chewing-gum...)'

In some Kanak languages, there are additional specific verbs for the ingestion of food types other than these canonical categories, as we will see in the following section.

3.2 SEMANTIC DISTINCTIONS. In addition to the generic term, as many as six specific 'eating' verbs are distinguished in Kanak languages, based on the food ingested. The largest set is composed of six different lexemes (as in the Hienghène languages: Jawe; Nemi; Fwâi; Pije; Pwapwâ and Pwaamei), whereas the minimal set is made up of three verbs (Loyalty Islands subgroup languages). Most common categories are sugarcane, starch and protein. However, in some languages starch and protein are combined into a single category. Table 13 in the appendix recaps all the documented forms for each of the twenty-two Kanak languages of the sample.

3.2.1 Generic verb. In all of the languages we studied, a generic verb is attested (see table 3). It can be employed to express the ingestion of any kind of food, when no specification of the latter is given. The generic 'eating' verb works as a large semantically neutral category in cases where the foodstuff does not belong to any specific food category distinguished in the language. It has a complement function rather than a default one: the generic 'eating' verb cannot work as a substitute for any specific 'eating' verb. ${ }^{10}$ For example, in Nengone (Bearune, p.c.), young children who would say *inu ci kaka guia 'I am eating meat' (with the general 'eating' verb, $k a k a$ ) would be corrected by older speakers because of the inadequate verb choice: inu ci ia guia 'I am eating meat' (with the specific verb for protein, $i a$ ).

$<$ table 3>

As we already mentioned in table 2, it is in the Loyalty Islands languages that POC *kani 'eating sth. (general); eating starchy food (TR)' has been better conserved. Cognates are recognizable in Drehu xen with the same meaning and in Iaai an exclusively for the transitive form for the generic. In other languages, the origin of the forms remains quite obscure.

3.2.2 Sugarcane. Concerning the specific verbs, the most commonly differentiated food category is sugarcane (in nineteen of the sample languages), with a relatively consistent lexical form, ranging from khuri (Nêlêmwa) to xhuli (Pwapwâ) or hwii (Tîrî and Iaai). Ross et al. (2016:234) list several terms reconstructed in POC for chewing without swallowing. One of them, POC *qusi- 'suck and chew (sugarcane)' might be the etymon of several of the New Caledonian terms shown in table 4.

$<$ Table 4>

Caac hиихис seems to be a lexicalization of the generic verb hии 'eat' plus incorporated object kuc 'sugarcane' to derive a specific verb form dedicated to this category of food.

8. Several kinds of barks or roots were traditionally consume by Kanak people, but are very rarely today: the root of magnania (Pueraria thunbergiana Benth., variant of Pueraria lobata, a fibrous root) and the bark of bourao (Hibiscus tiliaceus) are the most commonly known. It seems that they were earlier staples consumed as famine foods (Ross et al. 2008:256) or, on the contrary, as a "chief food" (Haudricourt 1964:97).

9. hoc is also a synonym verb in Iaai for eating chewable food (Ozanne-Rivierre 1984:53).

10. This distinction is well explained in relation to general classifier in Zubin \& Shimojo (1993). 
Ross et al. (2008:390) consider sugarcane (Saccharum officinarum) as one of the continuously cultivated plants for human consumption in Oceania and note that "the jointed, fibrous stalks contain sucrose, obtained by cutting off a stem and chopping it into convenient lengths which are sucked and chewed as a refreshing snack. When the sugar has been sucked out, the rubbish is spat out." Semantically, the verb used for 'eating sugarcane' more specifically describes an action of food extraction rather than a manner of food ingestion as a whole, chewing being the only way of ingesting sugarcane.

In Xârâcùù, the cognate term xwii is the specific verb for a larger category combining both sugarcane and chewable food. Only Cèmuhî (North Mainland) and Nengone (Loyalty Islands) completely lack this lexicosemantic categorization.

3.2.3 Proteins. Protein sources coming from animals were not present in every simple meal (Kinaston et al 2016), but were highly valued. A specific verb for eating proteins, consisting of animal flesh (meat, fish or seafood), coconut flesh or hard food is attested in seventeen languages of our sample, as for example hwii in Jawe; Nemi; Fwâi or also Pije. The origin of these forms remains uncertain, though some languages spoken in the North of the Mainland do have related forms, as shown in table 5.

\section{$<$ Table 5>}

Two languages spoken in the extreme southern Mainland do not include fish in the protein category: Numèe ( $k w e ̀$-re) has fish associated to the generic verb and Drubéa shows a similar kwè-re form for a larger semantic category including protein and some fruits and greens (see below), but not fish: kwè-re wââgòo 'eat fruits' (Shintani and Païta 1990:118). Nyelâyu (North Mainland) does not distinguish protein as a special category, but shares the use of $h u c$ for starch and protein. ${ }^{11}$ It is the only language in our sample that treats starch and protein as a single category. By contrast, Iaai, Vamale and Nêlêmwa do not have a specific verb for the protein category, but instead use the generic verb form.

3.2.4 Starchy food. Fifteen languages in our sample have a specific verb dedicated to 'eating starchy food' (yam; manioc; taro; sweet potatoes; banana; rice, etc.). As we stated previously in table 2, the specific verb for 'eating starchy food' is a reflex of POC *kani 'eat (generic)' in some of the North Mainland Kanak languages: cani in Jawe; Nemi; Fwâi; Pije and Pwapwâ and zani in Pwaamei.

Extreme southern Mainland languages and Loyalty Islands languages do not distinguish 'eating starchy food' as a lexico-semantic category. In Drubéa and Numèè, the generic 'eat' verb (respectively, kèrè-re and kii-rè) is used for both 'eating starchy food' and 'eating fish'. Also Drehu (Lifou, Loyalty Islands) uses its generic term xen for 'eating starchy food'. As previously mentioned, Nyelâyu shows a common undifferentiated semantic category for eating starchy food and proteins with huc.

\section{$<$ Table 6>}

Ross et al. (2008:255) specify that "A Proto Oceanic POC meal was typically made up of two categories of ingredient: *kanay 'staple food, starchy food' and *tamaji 'additional ingredients to accompany starchy food'. The main ingredients of *tamaji were - or rather are in today's Oceanic societies - green vegetables, $[\ldots]$ and coconut cream[...]." Thus, it is quite reasonable to consider that in many Kanak languages the POC generic 'eat' verb is the etymon for the verb meaning 'eat starchy food'. Furthermore, according to Ross et al. "there is almost never a separate verb meaning 'eat starchy food' in Oceanic languages". Thus, Kanak languages are particularly outstanding in this respect.

3.2.5 Chewable food. Thirteen languages in our sample have a specific verb for chewable foods, such as roots and barks (footnote 8), given in table 7. Ten of them are spoken in North Mainland, where there are quite stable forms: hwei hwai (Jawe Nemi; Fwâi and Pije); xhwei xhwai (Pwapwâ Pwaamei); fwai (Vamale); pwèi (Cèmuhî) or also pwé (Paicî); but maani in Caac. These verbs semantically express the action of 'chewing' the fibers of roots or barks, but not necessarily ingesting it.

\section{$<$ table $7>$}

In Xârâcùù, the verb xwii used for 'eating sugarcane' is also used for chewable food. Thus, xwii is used for a category of food stuff that are masticated, but not fully ingested (see appendix). Since it does not differentiate a specific restrictive 'chewable' category, it does not appear in table 7.

There is no evidence that Kanak forms are directly inherited from POC for which 'chew (betelnut, sugarcane), bite into' has been reconstructed as *yasu (INTR) or *yasi (TR) (Ross et al. 2016: 233).

3.2.6 Greens. A specific verb is found in twelve languages, all from North Mainland and none of the Loyalty Islands languages, to express the action of eating cooked leaves, greens or some fruits, without anything else, as shown in table 8 . 
$<$ Table 8>

According to Ross (2008:40), "Ramoaaina (Meso-Melanesian) odo and Arosi (Southeast Solomonic) yaukokona (lit. chew-smooth) are the only instances found in a survey of Oceanic dictionary sources" having this specific meaning 'eat greens alone'. In East Futunan, however, we also found the specific verb otai 'eat certain fruit (grated guava mixed with grated coconut)’ (Moyse-Faurie 1993:307).

One of the favorite green leaves to be cultivated and eaten (still today) is Abelmoschus manihot (Ross et al. 2008: 294), known in Caledonian French as chou kanak or 'island cabbage' in English. This plant is frequent and appreciated for being very nutritious and highly rich in protein. Interestingly, we note that in Drubéa (Shintani and Paita 1990:118), the action of eating greens can be expressed by kwè-re, the verb associated with proteins (except, fish which belongs to the generic), allowing a larger semantic category.

The origin of these forms found in Kanak languages is uncertain at the current stage of the study and reconstruction available for Proto New Caledonian. There is no evidence that they are reflexes of POC *tamaji 'additional ingredients to accompany starchy food (coconut milk; leafy vegetables and protein food (meat, fish, shellfish)'.

3.2.7 Raw food. Three languages (two spoken in the extreme north, one in the extreme south) have a specific verb for 'eat raw food or green/unripe fruits': thaxilo (Nyelâyu); thaxilolî (Nêlêmwa) and kwè-béríi-re (béríi 'premature [for food]') (Drubéa).

$<$ Table 9>

There is no evidence that these forms are reflexes of reconstructed POC *[k,q]oda(q) 'eat raw (meat, fish, shellfish)', whereas reflexes are found in Polynesian languages (Ross et al 1998:156-157), as we will see in section 4.2.

It is also worth mentioning at this point that the semantic differentiation found in Kanak languages shows many similarities with Aslian languages, ${ }^{12}$ in the domain of ingestion as well as in the fact of having "very detailed meanings encoded in single words, especially verbs, and in domains presumed to be fundamental to human experience" (Burenhult and Kruspe 2016:3).

3.2.8 Summary. This comprehensive look at the lexical resources for expressing eating events shows that:

1. Kanak languages have up to six verbs of eating, one of which has a "generic" meaning, used either when the thing eaten is not specified or when the language does not have a special verb for the given type of food.

2. Other verbs of eating are classified according to the category of food: sugarcane, chewable, starch, protein, greens, and raw food

3. While Kanak languages are unique in the large number of verbs of eating (above all, in some of North Mainland languages), no verbs of the specific category (e.g., 'eat starchy food') are unique to Kanak languages. Rather they all exist in other Oceanic languages and some can be traced back to POC (e.g. 'eating greens' attested in two languages from the POC Lexicon). However, many languages distinguish only one or two of these categories.

4. Therefore, what is unique about Kanak languages is not the categories they distinguish, but the number of categories for which special verb forms exist. ${ }^{13}$

However, it is still quite difficult to determine with certitude the reason that could explain this accumulation of lexico-semantic distinctions in some Kanak languages, but it seems still possible to formulate some cultural and environmental hypotheses:

- The absence of mammals and the extinction of some big birds (Anderson et al. 2010) led to increased consumption of vegetal protein sources, which generated a lexical diversification for this specific kind

- There is a huge biodiversity spread among large and diverse exploitable territories between the east and the west coasts of Mainland New Caledonia (Dotte 2010)

- Kanak culture is very keen to both preserve its diversity (as with the maintenance of an "egalitarian multilingualism") and to promote its micro-local idiosyncrasies (Moyse-Faurie and Rivierre 1992)

- Kanak culture is based on exchange between the different groups, favoring contacts, exchange of resources and inter-clan marriages (Sand et al. 2017)

\section{EXTENDING THE COMPARISON.}

4.1 FREQUENT CROSS-LINGUISTIC OBSERVATIONS. It is important to note that we freely make use in this paper of the translation 'eat' as a general and global cover term for actions and events that are, after all, quite

12. Aslian languages (about eighteen) are spoken in the mountain ranges of the Malay peninsula, and belong to the Austroasiatic language family.

13. It is worth saying that a parallel conclusion can be made about possessive classifiers dedicated to foodstuff in Kanak languages, as will be exemplified in Section 5 . 
different from the perspective of the speakers of Kanak languages. Actually, only the form labeled 'generic eat' could accurately correspond to the English translation to eat/eating (or to French manger). All the other specific verbs should receive a much more specific and accurate translation. It is in this perspective that we should keep in mind the statement of Wierzbicka (2009:88) asserting that "the conceptual categories 'eat' and 'drink' do not cut nature at its joints. The conceptualization of such activities depends, to some extent, on what is culturally salient in a particular society."

Given the basic and essential function of ingesting (solid) food, it is to be expected that the vast majority of languages of the world should have a basic verb denoting that activity. What is surprising, however, is that in many languages, these single basic verbs (e.g. English eat and French manger) correspond to several different verbs, whose selection depends on various factors (Næss 2011; Gast et al. 2014).

First, the verb is selected depending on the semantic type denoted by the subject (Who eats?), as in German essen versus fressen (humans versus animals) or English feed on sth. (intr.) only used of animals. While European languages have specific 'eat' verbs depending on the type of animals, such as French: brouter 'feed on grass (for cows)' and picorer 'peck (for birds)', Oceanic languages do not make any such distinction and use the basic 'eat' verb for all animals alike.

Second, the semantic type of the object (What kind of food is eaten?) can be the decisive factor. As we have seen above, Oceanic languages make use of this criterion. This distinction can focus on different characteristics: the form of the food stuff (round; long etc.), its nutritive properties (proteins; vegetables etc.), its consistency (and the related way it can be grabbed, moved from hand to mouth) or nature (fibrous stalk; raw food; mushy matter etc.). ${ }^{14}$

The third option is to select the verb depending on the manner of eating (How does one eat?), as in English. to wolf down, devour or German schlingen 'to wolf', fressen 'to stuff sth. down' versus speisen 'to eat'.

Fourth, it can also depend on the time of eating (When does one eat?), as found in French petit-déjeuner 'breakfast', déjeuner 'lunch', goûter 'eat at afternoon tea', dîner 'dine', and souper 'to have supper'.

Fifth, the place where one eats can be taken into account, such as in English eat out; French pique-niquer 'eat outdoors'.

Finally, the choice between ingestion verbs can be determined by a causative perspective: French nourrir 'to feed s.o.', allaiter 'to breast-feed', German füttern 'to feed animals, children, old or sick people', East Futunan mama ' $i$ ' 'to feed a child in the process of weaning by pre-chewing the food', and East Uvean pusiaki 'to feed with the hand (child, pig)'.

4.2 MAJOR DISTINCTIONS FOUND IN OCEANIC LANGUAGES. After having identified the contextual parameters that may be expressed by the relevant verbs in various Kanak languages, we will now try to achieve a more illuminating characterization by comparing the relevant lexical subsystems to those found in other Oceanic languages.

As we have seen in section 3, as many as six different specific categories of eating are distinguished in Kanak languages, in addition to the generic term. This is indeed remarkable, and not attested in other Oceanic subgroups. Kanak languages, and Kanak people, thus categorize their surrounding world with their own distinctions, which do not always match the Western-European ones. As already mentioned, two ways of organizing these 'ingestion' verbs exist in Kanak languages: the situation in the Loyalty Islands languages is less complex, and more similar to what is reconstructed for POC; while the most complex pattern is found in some northern languages of the Mainland, as Pije illustrates here with a range of six verbs:

(6) PIJE (North Mainland)

$\begin{array}{ll}\text { hwi-aman } & \text { 'eat (general term)' } \\ \text { hwii } & \text { 'eat protein, flesh, hard food...' } \\ \text { holi } & \text { 'eat sugarcane, some fruits' } \\ \text { cani } & \text { 'eat starchy food' } \\ \text { kaje } & \text { 'eat greens, leaves, fruits' } \\ \text { hwai } & \text { 'eat chewable barks, magnania' }\end{array}$

This peculiarity of highly detailed semantic granularity appears to be a micro-areal tendency in the northern region of mainland New Caledonia, in the 'eating' domain as much as in the 'drinking' domain, since it is also in these languages that we find distinct verbs for 'drinking' (i.e., 'liquid or juicy food ingestion') depending on the temperature of the drinkable liquid, as shown in table 10.

\section{$\langle$ Table 10>}

All Oceanic languages draw a lexical distinction between eating and drinking activities, thus differing from Papuan languages, such as Kalam, which has only one verb for 'eat' and 'drink', $\tilde{n} b$ - (Pawley and Bulmer 2011:437). According to Pawley (p.c.), Fijian has a clear dichotomy between foods that you 'eat' (kana in Bauan, kani in Wayan) and foods that you 'drink' (gunu in Bauan, som in Wayan), the latter including various kinds of wet/juicy foods, such as molluscs, sugarcane, juicy fruits, lollies, jelly or soup. We found an exception to this 
generalization in the honorific East Uvean language (used when you speak to/of the king) with only one verb, taumafa, meaning both 'drink' and 'eat', in contrast to the two different terms in the ordinary language, inu 'drink' and $k a i$ 'eat'. In East Futunan, in which there is no honorific versus ordinary language distinction, taumafa also exists, meaning 'eat with appetite, gladly drink', also showing no distinction between 'drink' and 'eat'.

A comparative perspective highlights the fact that in Polynesian languages verbs for 'eating' make other kinds of semantic distinctions ('raw' versus 'cooked food'; 'eating both starch food and meat/fish', 'eat only one thing at a meal'...). These distinctions are rarely attested in Kanak languages (Nyelâyu magilo 'eat without side dish', Ozanne-Rivierre 1998:120).

Specific terms such as 'eat fish, seafood, meat without anything else' are indeed not frequently found in Kanak languages, whereas they are frequent in Polynesian languages, and are also found in Anejom (South Vanuatu), and in Toqabaqita (Malaita, Solomon islands). More frequent is a specific term for 'eat both starch food and fish/meat', as it is also the case in Polynesian languages. Caac (Mainland, New Caledonia) shows a specific verb po cain for 'eating a mixture of foods' ("manger ensemble différentes sortes de nourriture, p. ex., pain et viande", ${ }^{15}$ Hollyman 1999:128).

In Polynesian languages, the general term for 'eat' kai (East Futunan, East Uvean, Tongan, etc.), is also used for any kind of food, but there are specific verbs for food combinations. First, some verbs denote 'drink while eating' or 'dunk food into water before eating it': East Uvean omaki (< Proto-Polynesian [PPN] *qomaki 'eat and drink at the same time'), and Tuvaluan ppeke (Besnier 2000:642); food eaten with kava: East Uvean fono $(<\mathrm{PPN}$ *fono); East Futunan mafana 'drink the juice of the dish su before eating it'.

Second, some Oceanic languages have verbs expressing the combination of both starch food and protein food, as in the following reflexes of PPN *kina 'food eaten with another food as relish: (kai)kina (East Uvean, West Uvean, East Futunan); Māori: kinaki 'meat or fish provided to eat with vegetable food, relish' (Williams 1971:118); East Uvean kīkī, Tuvaluan kiki (Besnier 2000). This combination is rare in Kanak languages (Cèmuhî wíi, Haméa hâwétè).

Third, verbs meaning to eat something raw (fish, meat, shells) are attested in the Polynesian languages, as shown by East Futunan, East Uvean 'ota, and Tuvaluan ota $<$ PPN *'ota < POC *[q,k]oda(q). In East Futunan, the reduplicated form 'ota 'ota means 'eat human flesh', along with fono ' $i$.

Finally, some languages have a verb meaning 'eat only one thing at a meal (starch food or bread without any meat or fish)', or vice versa 'eat leftovers (non-protein food)', such as East Uvean hamu/hamuko, East Futunan samukō, and Tuvaluan samusamu (Besnier 2000) from PPN *samu 'eat one thing only' (Greenhill and Clark 2011).

This comparative perspective highlights the fact that in Polynesian languages verbs for 'eating' are based on other kinds of semantic distinctions ('raw' versus 'cooked food', 'eating both starch food and meat/fish', 'eat only one thing at a meal', etc.) whereas, as we have seen, these distinctions are rarely attested in Kanak languages.

Verbs expressing different manners of eating or quantity of food ingested are attested in Kanak languages, although not as frequently recorded as in other Oceanic languages such as the following Toqabaqita and East Uvean examples:

(7) TOQABAQITA (Malaita, Solomon Islands)

(Lichtenberk 2008a)

dakufia TR 'eat hastily without chewing the food properly; gobble food; drink thirstily'

dudumeme INTR 'eat food, stuffing one's mouth full'

fangabusubusu INTR 'eat food, stuffing one's mouth full'

fangaliufaqadoqa INTR 'eat greedily; be a glutton (=fokobusubusu)'

luulua INTR 'eat too much, overeat'

luatania TR 'eat too much, overeat'

onoono INTR 'shove food down one's throat: a rude way of referring to eating'

simia TR 'eat every little bit of meat on a bone; pick on a bone'

(8) EAst UVEAN (Wallis and Futuna)
fa'apuku/ha'apuku
momi
pakalamu
'unani
'to stuff o.s.'
'swallow without chewing (ripe bananas), or when one has no teeth
'eat with noise (like animals)'
'enjoy eating'

Some languages have several terms expressing 'feel like eating specific kind of food', such as East Uvean and Tongan 'umisi 'crave for fish/seafood'. East Futunan $g \bar{a}$ and Fijian kusima 'crave for fish or meat' are non-cognate terms with a similar meaning. This type of specification is marginally attested in Kanak languages, having been recently found in Haméa (South Mainland) with treu 'crave for meat'.

4.3 REGISTER DIFFERENTIATION Register differentiation is not very frequent in Kanak languages, compared to other Oceanic languages. A few verbs, however, are attested for 'eating (general term)' in formal discourse, as addressing a chief or speaking of a chief: Nengone kodraru, Jawe, Fwâi, Pije, Vamale waadap, Nemi mooxon; Pwaamei, and Pwapwâ mawââdap but this last verb is noted as archaic.

In Toqabaqita, by contrast, Lichtenberk (2008a) lists several general 'eat' verbs, either transitive (TR) or intransitive (INTR), showing various degrees of politeness: 
(9) TOQABAQITA (Malaita, Solomon Islands)

$\begin{array}{lll}\text { qania } & \text { TR } & \text { 'eat (the common, ordinary word)' } \\ \text { fanga } & \text { INTR } & \text { 'eat; N food' } \\ \text { faqasobo } & \text { INTR } & \text { 'eat' } \\ \text { faqangado } & \text { INTR } & \text { 'eat (respect.)' } \\ \text { reqea } & \text { TR } & \text { 'eat (respect.) (= reereqe)' } \\ \text { masia } & \text { TR } & \text { 'eat (vulg.)' } \\ \text { nangasia } & \text { TR } & \text { 'eat (casul, jovial)' } \\ \text { onomia } & \text { TR } & \text { 'eat (impolite to use to adults)' } \\ \text { loqomia } & \text { TR } & \text { 'eat (vulg; used in anger)' } \\ \text { feqetania } & \text { TR } & \text { 'eat (vulg.); defecate out; (var. feqatania)' }\end{array}$

Toqabaqita also has verbs expressing inappropriate social behavior: fangaburi (INTR) 'without other people's permission or knowledge, help oneself to food left in the house after everybody else has gone', dатиа (TR) 'chew, eat; properly used only about animals'.

It is interesting to note that the Polynesian terms for good and bad behavior are based on PPN *kai 'eat', as, for example, in East Futunan along with the PPN terms found in Pollex-Online (Greenhill and Clark 2011): kai 'isi 'ask s.o. for sth. to eat' (PPN *kai-siqi 'beg, cadge'), kaimalie and kai solisoli (PPN *kai-mālie) 'be generous', kaimeo 'reproach s.o.', kainao 'adulterous', kaipō and kaiveli 'stingy', kai' 'a (PPN *kai-haqa) 'steal'.

Such specific terms are seldom listed in Kanak languages, though they are certainly attested, as it is the case in Haméa (South of the Mainland) with pâmîrî 'nibble'.

4.4 COLEXIFICATION Even if it does not reflect the POC etymon, it is significant to note that $d a$ 'eat (generic)' in Xârâcùu is polysemous and means also 'to cut; sharp' (Levinson 2007). This colexification (semantic association, cf. François 2008) is shared with POC:

whereby terms for 'sharp' (referring to a blade, not a point) are derived from the verb 'eat' or 'chew'.

Reflexes of *panan, often reduplicated, mean 'sharp' in a number of Meso-Melanesian and Southeast

Solomonic languages, while reflexes of *kani mean 'sharp' in a number of Northwest Solomonic,

Micronesian and Polynesian languages. Although this semantic extension of 'eat' seems rather an obvious

one, it is not among those listed as occurring cross-linguistically by Newman (2009) (Ross et al. 2016:226).

By metonymy, the partial aspect of eating allows the use of bite or cut for eat (bite > chew > swallow). In some languages indeed, the meaning of the verb is closer to the English verb bite and French mordre, as in Nyelâyu (see footnote 11), or in the example from Ajië given in (10) below. This case of colexification is also worthy of note.

(10) AJIË

$$
\begin{aligned}
& \mathrm{Na} \text { da öi ru xiyé na bwârâwê? } \\
& \text { 3SG NEG bite 3DU why MS dog } \\
& \text { 'Why does the dog not bite them?' }
\end{aligned}
$$

(Lercari 2002:251)

\section{FOOD POSSESSIVE CLASSIFIERS.}

5.1 SEMANTIC DISTINCTIONS. Oceanic languages are well known for manifesting a wide range of possessive classifiers (Lichtenberk 2009) involved in indirect possessive constructions. ${ }^{16}$ Consumable items represent a crucial semantic category as the average set of possessive classifiers among the Oceanic languages consists of a binary distinction between a general class and a consumable class including both food and drink (see, for example, Manam from Papua New Guinea in Lichtenberk 1985:105). Furthermore, POc has been reconstructed with (at least) a system of three possessive classifiers based on the distinction of general (*na-) / foods (*ka-)/ drinks (*m(w)a-) (Lichtenberk 2018; Lynch et al. 2002). According to Lichtenberk (2013), the edible-based distinction within the category devoted to alienable relationship goes back to an Oceanic innovation within the Austronesian family. ${ }^{17}$

At least fifteen Kanak languages have a possessive classifier system and all of them retain the kind of food as a distinguishing criterion (table 11).$^{18}$ The categories of food nouns that are distinguished are one generic category and up to seven specific ones. Six correspond to the semantic categories detailed earlier for verbs: sugarcane; protein; starchy food; chewable barks; greens, leaves and some fruits; green or unripe fruits; whereas two languages add a specific class for the possessive expression of 'fish/shellfish'.

16. In Oceanic languages, it is very common to differentiate between nouns depending on how they combine with possessive suffixes: if the possessive morpheme is directly suffixed to the noun, this indicates direct possession for a dependent noun, as in Iaai benyin 'his/her hand', benyâm 'your hand'. Indirect possession, by contrast, is expressed by constructions for independent nouns, in which the possessive suffix is affixed to a classifier (itself a dependent noun that provides complementary information about the relation between the possessee and the possessor): haaleem kuli 'your dog (pet)', haaleeny pusi 'his/her cat (pet)'.

17. "While it is possible that the existence of the alienable-inalienable contrast was due to contact with one or more Papuan languages, the distinctions within the alienable category for food, drink, or alimentary (food-drink), and other, general possession, are not found in the Papuan languages and are clearly a development or developments internal to Austronesian" (Lichtenberk 2013:16).

18. Kanak languages differ in the ways the category of free nouns encodes the expression of possession. It can be indirect, making necessary the use of a possessive classifier, as in Iaai; mediate, with a possessive relator or preposition, as $i$ in Drehu; semi-mediate, with a lengthening of the final vowel, for example in Xârâcùù; or, finally, immediate, as in Caac for both bound nouns and some possessible free nouns. 
<Table 11>

Interestingly, Iaai (Loyalty Islands), which has the largest inventory of possessive classifiers (around twentythree, see Dotte 2013,2017), only shows three categories based on a semantic differentiation of the 'type of food':

(11) IAAI (Loyalty Islands)

$\begin{array}{llll}a-n & \text { P_CL.FOOD-3SG } & \text { an koko } & \text { 'his/her (food) yam' } \\ \text { iie- } n & \text { P_CL.SUGARCANE-3SG } & \text { ieen aakû } & \text { 'his/her (sugarcane) sugarcane' } \\ \text { hice- } n & \text { P_CL.CHEWABLE-3SG } & \text { hicen waasu } & \text { 'his/her (chewing) bark' }\end{array}$

Like Iaai, many Micronesian languages have a large paradigm of possessive classifiers, but with only few specifications (in the same language) related to the edible semantic domain. For example, Ponapean has only edible (kene) and drinkable (nime) possessive classifiers (Rehg and Sohl 1981). Mokilese has edible (kanah); drinkable (nimah) and chewing (ngidah) (Song 1997). Kusaiean (ibid.) and Trukese (Sugita 1987) have possessive classifiers for food (Kusaiean $n a$, Trukese ana-), drink (nihmac and wúnúma- respectively), raw/uncooked food (osrwac and wochaa-) and chewable (niyac and ngúta-).

What is noticeable in Kanak languages is that, if a language has a possessive classifier system (even a reduced one), then the edible domain will be one of its categories. Moreover, it is likely that it has more than three categories of food distinguished by different possessive classifiers. Even if possessive classifiers systems in Kanak languages are not among the largest ones within the Oceanic subgroup (with the exception of Iaai), the semantic granularity related to food is one of the most sophisticated (Dotte 2013; 2017).

\subsection{COMPARISON BETWEEN POSSESSIVE CLASSIFIERS AND VERBS IN THE 'EATING'}

LEXICAL CATEGORIES. Cross-linguistically, possessive classifiers are mainly derived from verbs (Craig 1992:290). Nevertheless, there are not always exact correspondences between the 'eating' verb and the 'food' possessive classifier in the Kanak languages, even if some matches are relevant.

Once again, the languages from the Hienghène region (Fwâi, Nemi, Jawe, and Pije in the northern Mainland of New Caledonia) are the ones that display the widest range of possessive classifiers dedicated to specific kinds of food. Illustrative examples in Fwâi are provided in table 12:19

\section{<Table 12>}

These examples in Fwâi highlight the clear relation between the forms of eating verbs and the possessive classifiers for corresponding semantic domains. Only kuu- in table 12 has a more distant form from the verbal form kaje but we can reasonably hypothesize a borrowing process here. Actually, in Jawe, one of Fwâi's sister languages from the Hienghène region, kuuni is the verb for 'eat greens' and seems to be related to the possessive classifier kuu-, which is common for all the four languages in the region: Pije, Fwâi, Nemi and Jawe. It is interesting to note that Caac, spoken a few kilometers further to the north of the Mainland east coast, also has the same verb kuuni for the same meaning. On the contrary, Pije, Fwâi and Nemi use the verb kaje 'eating cooked leaves, salad, some fruits', which is very close in its form to xaje in Vamale, one of the Voh-Koné dialects spoken further to the south. Thus, we can assume that the original verb in Pije, Fwâi, Nemi and Jawe was kuuni (as it is still attested in Caac), which generates the form $k u u$ - for the associate possessive classifier. Later, Pije, Fwâi and Nemi borrowed xaje from the southern neighbor Vamale (rephonologized in kaje, with a fortition of the initial velar consonant), blurring the correspondence between the verb and the possessive classifier in these three languages, whereas Jawe conserved the original verb-classifier relation.

A second observation on these Fwâi examples concerns the forms in rows b. and c. in table 12, two distinct possessive classifiers, encoding two semantic categories ('portion of shellfish' versus 'portion of meat or fish'), whereas the verbal forms are merged in the verbal paradigm with one common form hwii. However, whether this is due to the loss of the verbal distinction or from the innovation in the possessive classifier paradigm is impossible to tell at this stage of the study.

It appears that the semantic field of 'food' and 'drink' is of a special importance in this area, maybe more than in other parts of New Caledonia, and that this emphasis plays a significant role as a categorizing criterion in the lexicon but also in the morphosyntax of the local languages.

In other Kanak languages showing possessive classifiers dedicated to food categories, the match between verb and classifier is less systematic. Possessive classifiers in Iaai are often derived from corresponding verbs, for example $a-n$ 'P_CL.FOOD-3SG' < an 'eat (generic, TR)' and hice-n 'P_CL.CHEWABLE-3SG' < hic $\hat{a}$ 'eat chewable food (barks, chewing-gum etc.)'. However, there is no clear etymological link between hwii 'eat (or gnaw) sugarcane' and the possessive classifier for the corresponding category of one's portion of sugarcane $i e-n$, whose origin remains uncertain. Nevertheless, the interesting thing to note here is that the semantic category is distinguished within both the verbal and the nominal lexical domains in this language.

The case of Nêlêmwa (North Mainland; Bril 2002:364-365) is slightly different as caa- 'P_CL.STARCHES' cannot be related to any corresponding verb for starchy food consumption. The semantic category does exist in

19. There is also an attested possessive classifier for drinks (cold beverage) khûdoo- $n$ clearly derived from the equivalent verb khûduk khûdi 'to drink water, cold beverage'. 
the scope of the possessive classifier system, but is missing in the verbal one. Four of the other 'eating' verbs attested in Nêlêmwa are etymologically related to corresponding food possessive classifiers: ${ }^{20}$ khuri 'eat sugarcane' > khora- 'P_CL.SUGARCANE (portion of sugarcane or of a specific variety of coconut)'; kûûri 'eat greens, leaves, fruits' > kûû- 'P_CL.GREENS (portion of greens, leaves, fruits)'; maa 'to masticate > maa- 'P_CL. CHEWABLE'; ${ }^{21}$ and thaxilol $\hat{\imath}$ 'eating green or unripe fruits' > thaxilo- 'P_CL. UNRIPE'. Finally, the classifier khoo'P_CL.PROTEIN' used for the possession of a portion of protein food (meat, fish, turtle, coconut flesh etc.) is etymologically related to khuwo 'eat (generic)', whereas there is no specific verb for 'eating protein food' in Nêlêmwa. The semantic scope of the generic verb seems to have narrowed until focusing on the specific type of protein/fleshy food in the case of the possessive classifier.

If it is true that there is a core semantic match between eating verbs and possessive classifiers devoted to food portions in Kanak languages, a perfect correspondence is almost never found. What is clear, however, is that the semantic domain of food and eating is a crucial culturally salient domain that is very specifically encoded in the lexicon and the morphosyntax of a large part of the Kanak languages by verbs and by possessive classifiers (Boawe and La Fontinelle-Kasarhérou 2020; and see Grinevald 2016 for the discussion of the relationship between classifiers and salient cultural domains).

6. MORPHOSYNTACTICAL CONSIDERATION. The preceding discussion of semantic differentiations in 'eating' verbs would be incomplete without a look at their morphosyntactic properties, especially their valency, from a typological perspective (Newman 2009). In cross-linguistic studies verbs of eating are frequently described as not behaving like ordinary transitive verbs (Næss 2011), occurring in different types of constructions, in relation to the degree of affectedness, and showing selective restrictions on the Patient (Gast et al. 2014).

From a morphosyntactic perspective, generic 'eating' verbs in Oceanic languages fall into three types in terms of how transitivity is encoded:

1. Intransitive and transitive verbs are two separate lexical items (section 6.1).

2. The transitive form is derived from the intransitive one (section 6.2).

3. Labile verbs which can be used both intransitively or transitively; or in some cases with an oblique object (section 6.3).

6.1 LEXICAL DIFFERENTIATION BETWEEN INTRANSITIVE AND TRANSITIVE VERBS. As already mentioned, POC distinguished between intransitive and transitive verbs with *payan 'eat (INTR)' and *kani 'eat (TR)'. The intransitive verb *payan has few reflexes in Oceanic languages, having often been replaced by reflexes of *kani, the transitive verb.

The distinction between a transitive and an intransitive generic 'eating' verb has been maintained in some languages, such as Toqabaqita (Solomon Islands), with an intransitive 'eat' verb, fanga, "which [does] not carry any inflectional morphology", and which cannot take an object (Lichtenberk 2008b:60), versus a transitive verb, qania. An example of Toqabaqita intransitive fanga 'eat' is given in (12) below.

(12) TOQABAQITA

$\begin{array}{llll}\mathrm{Na} & \mathrm{ku} \text { fanga sui naqa } \\ \mathrm{u} & & \\ \text { 1SG 1SG.NFUT eat } & \text { COMPL } & \text { PRF } \\ \text { 'I have finished eating.' }\end{array}$

(Lichtenberk 2008b:60)

An intransitive 'eat' verb is also found in Anejom (Vanuatu) with hag [han] 'eat' INTR (< POC *payan), versus the transitive counterpart ciñ [yiñ] 'eat' TR (< POC *kani) (Lynch and Tepahae 2001).

6.2 A PAIR OF VERBS WITH TWO COGNATE FORMS. In Boumaa Fijian, according to Dixon (1988:227), there are two forms, 'ana (intransitive form) and 'ani-a (transitive, A type verb, that is, "the focus is on the person who eats"). The intransitive form occurs when the object is incorporated, as shown in (13b)

(13) BOUMAA FIJIAN

a. E 'ani-a a uto.

NPST eat-TR ART breadfruit

'He is eating the/some breadfruit.'

b. E 'ana.uto

NPST eat.breadfruit

'He is eating breadfruit.'

In Samoan, there are also two cognate forms for the verb 'eat': 'ai and 'aina (Milner 1966:9). They can both occur with two arguments:

20. Nêlêmwa is the Kanak language with the second most extensive classifier system, with a dozen of them (Bril 2002:364-67)

21. maa in the Poum dialect and hmaa in the Koumac dialect. 
(14) SAMOAN

'Ua 'ai e loi suka.

PFV eat ERG ant sugar

'He is eating the/some breadfruit.'

(15) $\mathrm{Na}$ 'aina talo e pua'a.

PST eat.SUF taro ERG pig

'He is eating breadfruit.'

But when only one argument is expressed, it will refer to the agent (with 'ai) or to the patient, with 'aina as in the following example:

(16) SAMOAN

$$
\begin{aligned}
& \text { Sā 'aina le fāsipovi } \\
& \text { PST eat.suF SPC piece.of.beef } \\
& \text { 'The piece of beef was eaten.' }
\end{aligned}
$$

According to Pawley (p.c.), 'aina, which Milner glosses 'perfective', seems to behave like a typical ergative verb, except that it has the sense of 'eat up, be eaten up, completely eaten'.

Some Kanak languages have two cognate forms for the same generic 'eat' verb according to the valency or the degree of definiteness of the object: Iaai has han when occurring by itself (ame han 'he is eating') or an indefinite object (ame han koko 'he is eating yams'), but an when followed by a specific object (ame an koko 'he is eating the/a yam').

Fagauvea/West Uvean, the Kanak Polynesian Outlier spoken in Ouvéa (Loyalty Islands), which inherited several Samoan features (Moyse-Faurie 2000), has kept both forms: an intransitive one, kai, and a derived transitive one, kaina.

Kai occurs in intransitive constructions, either by itself (17), or followed by an incorporated object (18b); while kaina occurs in a transitive construction, with a specific object (19) which can remain unexpressed (18a):

$$
\begin{aligned}
& \text { FAGAUVEA/WEST UVEAN } \\
& \text { I de kai i de pō } \\
& \text { 3SG NPST eat.INTR OBL SPC night }
\end{aligned}
$$

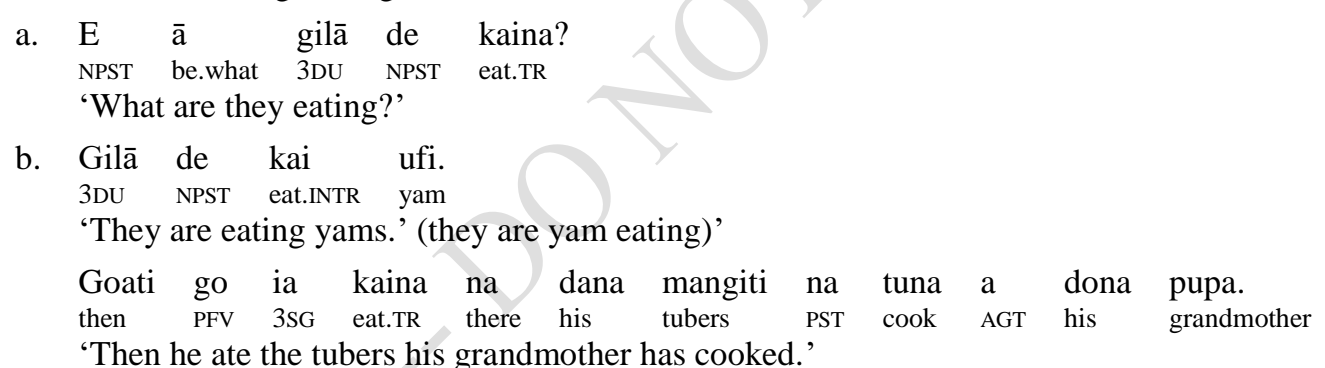

\subsection{LABILE VERBS WHICH CAN BE USED BOTH INTRANSITIVELY AND TRANSITIVELY. In}

Wayan (West Fijian), contrasting with Boumaa Fijian, the verb kani 'eat' is an actor subject verb, either transitive or intransitive. When followed by certain adjectives it is intransitive with the meaning 'have a certain taste', for example kani vinā (lit. eat good) 'be good tasting, be good eating', with an undergoer subject, for example sā kani vinā na magiti (PFV/eat/good/ART/meal) 'the meal tasted good' (Pawley, p.c.).

Similarly, about half of the Kanak languages have only one verb for 'eat (in general)'. This 'eat' verb can occur with or without an object, without any formal change, as in Xârâcùù examples (20) and (21), respectively:
(20) XÂRÂCÙÙ

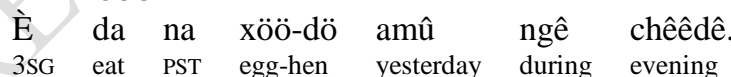
'He ate eggs yesterday night.'
(21) Îrî nää $\quad$ sae caa mè $\quad$ rî da.
'We used to hunt each time in order to eat.'

The Kanak eating verbs for 'ingestion of specific kinds of food', however, are different: they must co-occur with an overt object:

$$
\begin{aligned}
& \text { Nâ kê ku. } \\
& \text { 1sG eat.tubers yam, } \\
& \text { 'I am eating yams.' }
\end{aligned}
$$

$$
\begin{array}{ll}
\text { nâ } & \text { kê } \\
1 \text { SG } & \text { eat.tubers }
\end{array}
$$

To conclude, regarding the syntactical aspect of the generic 'eat' verbs both cases are found depending on the construction. If the construction is intransitive, it is the generic 'eat' verb which is used, pointing out the agent and the eating activity. In transitive constructions, the action is patient-oriented, whether the patient is overtly 
expressed or not. With non-generic 'eat' verbs, by contrast, the object is obligatorily expressed. In both cases, however, the activity is always patient-oriented.

7. CONCLUSIONS. Our comparative survey shows that the different verbs used to describe the action of eating (even in the more general sense) do not relate to exactly the same type of food in the different Kanak languages. Each language can have its own inventory of 'eating' verbs and an association with food nouns, but specific shared categories clearly stand out, depending on physical, nutritive or symbolic (cultural) criteria.

All languages have a generic 'eat' verb, along with additional verbs of 'eating', used for specific types of foods (e.g., sugarcane, starchy food, greens, chewable, raw meat, etc.); but the categorization of different types of food is not uniform across Kanak languages, and the number of these specific verbs of 'eating' vary.

Furthermore, this cross-linguistic study reveals that the different patterns are distributed areally, with the main contrast between the Loyalty Islands and New Caledonian Mainland.

The languages of the Loyalty Islands show a three-term opposition: the general term for 'eating' (which is also used for 'eating starchy food'), and two other 'eating' terms: one for chewable food (in Iaai and Nengone), one for sugarcane (in Iaai and Drehu), and one for protein (in Drehu and Nengone).

North Mainland languages spoken in the Hienghène area (Jawe, Nemi, Fwâi, Pije on the east coast, plus Pwapwâ and Pwaamei on the west coast) have a much larger set of 'eating' verbs with six different lexico-semantic categories, that is to say all the mentioned categories excluding 'eating raw food; green fruits' (only attested in the far northern Mainland languages Nyelâyu and Nêlêmwa, and Drubéa in the southern Mainland). Southern Mainland languages show therefore a transition between the minimal and the maximal systems, with three (Numèè) to five (Ajië) categories.

It appears that the idiosyncrasy of Kanak languages is that they concentrate all the different semantic categories of 'eating' verbs available in the Oceanic subgroup. These languages did not innovate in coining new categories or distinctions, but they differentiate themselves in combining or reorganizing this range of verbs. Strikingly, the encoding of each Kanak 'eat' verb is very similar to what is found in the northern Aslian language Jahai, spoken by subsistence foragers, showing four main distinctions: 'eat starchy food', 'eat leafy greens', 'eat ripe-fruit' and 'eat animal' (Burenhult and Kruspe 2016:5), despite the fact that the Aslian remained foragers while the Kanak rapidly combined agricultural resources with forest subsistence.

This large array of semantic granularity found in the verbal lexical domain of Kanak languages is also relevant as far as possessive classifiers systems are concerned in these languages. Indeed, indirect possessive constructions involving edible items also provide information on the noun class with which it is associated through the choice of the possessive classifier. If it is true that Oceanic languages typically have elaborate systems of possessive classifiers, Kanak languages are particularly significant in the use they make of such rich systems mainly based on the criterion of the nature of food.

Finally, we turned our attention to morphosyntactic characteristics of the Oceanic 'eating' verbs. It is crosslinguistically well attested that the verbs for "eat' "are two-participants verbs, but not necessarily transitive verbs" as pointed out by Næss (2011:414), since they often occur without an object. In the Oceanic languages which retained reflexes of both the intransitive and the transitive POC verbs, or which have two different forms for the same verb according to the valency, the situation is even more complex. In any case, however, the transitive verb is always patient-oriented: the patient is optionally expressed with generic 'eat' verbs, and obligatorily expressed with non-generic ones. Indeed, in Kanak languages, the main parameter associated with the basic action of eating is what is eaten. The selection of a verb typically depends on the meaning of the object, that is, on the type of food that is eaten, along with the manner of eating it.

\section{APPENDIX}

$<$ Table 13>

\section{References}

Anderson, Atholl, Christophe Sand, Fiona Petchey, and Trevor H. Worthy. 2010. Faunal extinction and human habitation in New Caledonia: Initial results and implications of new research at the Pindai Caves. Journal of Pacific Archeology 1(1): 89-109.

Bataillon, Pierre. 1932. Langue d'Uvea (Wallis). Grammaire-dictionnaire uvea-français. Dictionnaire français-uvea-anglais. Paris: Librairie orientaliste Paul Geuthner.

Besnier, Niko. 2000. Tuvaluan. A Polynesian language of the Central Pacific. London/New York: Routledge.

Blust, Robert A. 2009. The Austronesian languages. Canberra: Pacific Linguistics.

. 2017. Historical linguistics and archeology: An uneasy alliance. In New perspectives in Southeast Asian and Pacific prehistory, ed. by Philip J. Piper, Hirofumi Matsumura, and David Bulbeck, 275-91. Canberra: Australian National University Press.

Boawe, Yvette, and Jacqueline de La Fontinelle-Kasarhérou. 2020. Vivres et vivre en terre A 'jië. Cuisine et culture en NouvelleCalédonie: témoignage en langue a'jië, traduit en français et anglais. Nouméa: Académie des Langues Kanak.

Bril, Isabelle. 2000. Dictionnaire nêlêmwa-nixumwak-français-anglais. Paris: Peeters. 
2002. Le nêlêmwa, Nouvelle-Calédonie : analyse syntaxique et sémantique. Paris: Peeters.

Burenhult, Niclas, and Nicole Kruspe. 2016. The language of eating and drinking: a window on Orang Asli meaning-making. In Malaysia's original people: Past, present and future of the Orang Asli, ed. by K. Endicott, 175-99. Singapore: National University of Singapore Press.

Cauchard, Aurélie. 2018. Spatial expression in Caac: An Oceanic language spoken in the north of New Caledonia. Pacific Linguistics Series, 650. Berlin: De Gruyter Mouton.

Craig, Colette. 1992. Classifiers in a functional perspective. In Layered structure and reference in a functional perspective, ed. by M. Fortescue, P. Harder, and L. Kristoffersen, 277-301. Amsterdam/Philadelphia: John Benjamins Publishing Company.

Dixon, Robert M. A. 1988. A grammar of Boumaa Fijian. Chicago: University of Chicago Press.

Dotte, Anne-Laure. 2013. Le iaai aujourd'hui: évolutions sociolinguistiques et linguistiques d'une langue kanak de NouvelleCalédonie (Ouvéa, Iles Loyauté). PhD diss., Université Lumière-Lyon 2.

. 2017. Dynamism and change in the possessive classifier system of Iaai. Oceanic Linguistics 56(2): 339-63.

Dotte, Émilie. 2010. Modes d'exploitation et d'intégration au sein des territoires kanak précoloniaux des ressources végétales forestières ( $\mathrm{II}^{\mathrm{e}}$ millinéaire apr. J.-C.): approche ethno-archéo-anthracologique en Nouvelle-Calédonie. Territoires et économies / Actes de la $2^{e}$ Journée doctorale d'archéologie, 155-89. Paris: Publication de la Sorbonne.

Ehrhart, Sabine. 2012. L'écologie des langues de contact: le tayo, créole de Nouvelle-Calédonie. Paris: L'Harmattan.

François, Alexandre. 2008. Semantic maps and the typology of colexification: Intertwining polysemous networks across languages. In From polysemy to semantic change, ed. by Martine Vanhove, 163-215. Amsterdam: John Benjamins.

Gast, Volker, Ekkehard Koenig, and Claire Moyse-Faurie. 2014. Comparative lexicology and the typology of event descriptions: A programmatic study. In Meaning and grammar of nouns and verbs, ed. by Doris Gerland, Christian Horn, Anja Latrouite, and Albert Ortmann, 145-83. Studies in Language and Cognition, 1. Düsseldorf: Düsseldorf university press.

Greenhill, Simon J., and Ross Clark. 2011. POLLEX-Online: The Polynesian Lexicon Project Online. Oceanic Linguistics 50(2): 551-59.

Greenhill, Simon J., Robert Blust, and Russell D. Gray. 2008. The Austronesian basic vocabulary database: From bioinformatics to Lexomics. Evolutionary Bioinformatics 4: 271-83.

Grinevald, Colette. 2016. The Jakaltek Popti' noun classifier system: changes due to Spanish contact. In Language contact and change in the Americas. Studies in honour of Marianne Mithun, ed. by Berez-Kroeker, Diane M. Hintz, and Carmen Jany, 273-95. Amsterdam: John Benjamins.

Haudricourt, André-Georges. 1961. Richesse en phonèmes et richesse en locuteurs. L'Homme 1(1): 5-10.

. 1964. Nature et culture dans la civilisation de l'igname : l'origine des clones et des clans. L'Homme 4(1): 93-104.

1971. New Caledonia and the Loyalty Islands. Current Trends in Linguistics 8: 359-396.

Haudricourt, André-Georges, and Françoise Ozanne-Rivierre. 1982. Dictionnaire thématique des langues de la région de Hienghène (Nouvelle-Calédonie). Paris: Peeters-Selaf.

Haudricourt, André-Georges, and Pascal Dibie. 1987. Les pieds sur terre. Paris: Editions A.-M. Métailié.

Hollyman, Kenneth J. 1987. De muna fagauvea. Dictionnaire fagauvea-français. Auckland: Linguistic Society of New Zealand.

- 1999. Études sur les langues du Nord de la Nouvelle-Calédonie. Paris/Louvain: Peeters. unpublished. Dictionnaire de la langue caaàc.

Kinaston, Rebecca, Stuart Bedford, Matthew Spriggs, Dimitri Anson, and Hallie Buckley. 2016. Is there a 'Lapita diet'? A comparison of Lapita and post-Lapita skeletal samples from four Pacific Island archeological sites. In The Routledge handbook of bioarcheology in Southeast Asia and the Pacific Islands, ed. by Marc Oxenham and Hallie Buckley, 42761. Oxon/New York: Routledge.

Kirch, Patrick V. 2000. On the road of the winds: An archeological history of the Pacific Islands before European contact. Berkeley: University of California Press.

Lercari, Claude. 2002. Dictionnaire ajië-français à l'usage des étudiants. Langue de la région de Houaïlou (NouvelleCalédonie). Nouméa: CDP Nouvelle-Calédonie \& Laboratoire Transcultures de l'Université de Nouvelle-Calédonie.

Levinson, Stephen C. 2007. Cut and break verbs in Yeli Dnye, the Papuan language of Rossell Island. In The semantic categories of cutting and breaking events: A crosslinguistic perspective, ed. by Asifa Majid, Melissa Bowerman, Miriam Van Staden, and James S. Boster. Cognitive Linguistics 18-2: 319-30.

Lichtenberk, Frantisek. 1985. Possessive constructions in Oceanic languages and in Proto Oceanic. In Austronesian linguistics at the 15th Pacific Science Congress, ed. by Andrew Pawley and Loi Carrington, 93-140. Honolulu: Pacific Linguistics.

. 1994. The raw and the cooked: Proto Oceanic terms for food preparation. In Austronesian terminologies: Continuity and change, ed. by Andrew K. Pawley and Malcolm D. Ross, 267-88. Canberra: Pacific Linguistics.

2008a. A dictionary of Toqabaqita (Solomon Islands). Canberra: Pacific Linguistics.

2008b. A grammar of Toqabaqita. Berlin/New York: Mouton de Gruyter.

2009. Oceanic possessive classifiers. Oceanic Linguistics 48: 379-402.

2013. The rise and demise of possessive classifiers in Austronesian. In Historical Linguistics 2011: Selected papers from the 20th International Conference on Historical Linguistics, ed. by Ritsuko Kikusawa and Lawrence A. Reid, 199225. Amsterdam/Philadelphia: John Benjamins.

- 2018. The diachrony of Oceanic possessive classifiers. In Diachrony of classification system, ed. by William B. McGregor and Søren Wichmann, 165-200. Amsterdam/Philadelphia: John Benjamins.

Lynch, John, and Philip Tepahae. 2001. Añejom dictionary. Canberra: The Australian National University.

Lynch, John, Malcolm Ross, and Terry Crowley. 2002. The Oceanic languages. Richmond: Curzon.

Milner, George B. 1966. Samoan dictionary. Aotearoa, New Zealand: Polynesian Press.

Moyse-Faurie, Claire. 1993. Dictionnaire futunien-français. Louvain/Paris: Peeters.

. 2000. A syntactic approach to Fagauvea (WUV), in Leo Pasifika. Proceedings of the Fourth International Conference on Oceanic Linguistics, Niue, The Institute of Polynesian Languages and Literatures, Auckland, July 5-9, 1999, $233-59$. 
Moyse-Faurie, Claire, and Jean-Claude Rivierre. 1992. Langues. In Nouvelles Calédonies d'avant 1914, ed. by Association Pacifique, 36-43. Paris: Association Pacifique.

Moyse-Faurie, Claire, and Marie-Adèle Néchéro-Jorédié. 1989. Dictionnaire xârâcùù-français (Nouvelle-Calédonie). Nouméa: EDIPOP Les Editions Populaires.

Moyse-Faurie, Claire, Jean-Claude Rivierre, and Jacques Vernaudon. 2012. Les langues kanak. In Atlas de la NouvelleCalédonie, ed. by Jacques Bonvallot, Jean-Christophe Gay, and Elisabeth Habert, 119-22. Marseille/Nouméa: IRD \& Congrès de la Nouvelle-Calédonie.

Næss, Åshild. 2011. The grammar of eating and drinking verbs. Language and Linguistics Compass 5(6): 413-23.

Newman, John, ed. 2009. The linguistics of eating and drinking. Amsterdam/Philadephia: John Benjamins Publishing Company.

Noury, Arnaud, and Jean-Christophe Galipaud. 2011. Les Lapita, nomades du Pacifique. Marseille: IRD éditions.

Osumi, Midori. 1995. Tinrin Grammar. Honolulu: University of Hawai'i Press.

Ozanne-Rivierre, Françoise. 1984. Dictionnaire iaai-français (Ouvéa, Nouvelle-Calédonie) : suivi d'un lexique français-iaai. Paris: Société d'études linguistiques et anthropologiques de France.

. 1992. The Proto Oceanic consonantal system and the languages of New Caledonia. Oceanic Linguistics 31(2): 191207.

1998. Le nyelâyu de Balade (Nouvelle-Calédonie). Paris: Peeters.

2007 [unpublished]. Dictionnaire thématique des langues pwaamei hnaakâ, pwaamei yaak et pwapwâ.

Pauleau, Christine. 1995. Le français de Nouvelle-Calédonie: contribution à un inventaire des particularités lexicales. Vanves: EDICEF/AUPELF.

Pawley, Andrew. 2017. Were the first Lapita colonisers of remote Oceania farmers as well as foragers? In New perspectives in Southeast Asian and Pacific prehistory, ed. by Philip J. Piper, Hirofumi Matsumura, and David Bulbeck, 293-310. Canberra: Australian National University Press.

Pawley, Andrew, and Ralph Bulmer. 2011. A dictionary of Kalam with ethnographic notes. Canberra: The Australian National University.

Pawley, Andrew, and Roger Green. 1984. The Proto Oceanic community. The Journal of Pacific History 3-4(19): 123-46.

Rehg, Kenneth, and Damian Sohl. 1981. Ponapean reference grammar. Honolulu: The University Press of Hawai' ${ }^{\circ}$.

Rice, Sally. 2009. Athapaskan eating and drinking verbs and constructions. In The linguistics of eating and drinking, ed. by John Newman, 109-50. Amsterdam/Philadephia: John Benjamins Publishing Company.

Rivierre, Jean-Claude. 1983. Dictionnaire paicî-français (Nouvelle-Calédonie) (suivi d'un lexique français-paicî). Paris: SELAF.

- 1994. Dictionnaire cèmuhî-français, suivi d'un lexique français-cèmuhî. Paris: SELAF.

Rivierre, Jean-Claude, en collaboration avec Clément Vandegou. unpublished. Lexique numèè-français. Paris: Lacito-CNRS.

Rivierre, Jean-Claude, and Sabine Ehrhart. 2006. Le bwatoo et les dialectes de la région de Koné, Nouvelle-Calédonie. Paris: Peeters.

Ross, Malcolm. 2008. Introducing Proto Oceanic plant names. In The Lexicon of Proto Oceanic culture and environment of ancestral Oceanic society, ed. by Malcolm Ross, Andrew Pawley, and Meredith Osmond, 25-52. Canberra: The Australian National University.

Ross, Malcolm, Andrew Pawley, and Meredith Osmond. 1998. The Lexicon of Proto Oceanic culture and environment of ancestral Oceanic society/Volume 1: Material Culture. Canberra: The Australian National University.

- 2008. The Lexicon of Proto Oceanic culture and environment of ancestral Oceanic society / Volume 3 : Plants. Canberra: The Australian National University.

- 2016. The Lexicon of Proto Oceanic culture and environment of ancestral Oceanic society / Volume 5 : People: body and mind. Canberra: Pacific Linguistics.

Sam, Drilë, Léonard. 2009. Dictionnaire drehu-français. Nouméa: ALK \& CDPNC.

Sand, Christophe, Russell Beck, Yoshiyuki Iizuka, and Christophe Adams. 2017. Le « cycle de jade » kanak. Réévaluation archéologique d'un réseau d'échanges traditionnels (Mélanésie du Sud). Journal de la Société des Océanistes 144145:269-98.

Shintani, Tadahiko L.A., and Yvonne Païta. 1990. Dictionnaire de la langue de Païta. Nouméa: Société d'études historiques de la Nouvelle-Calédonie 43.

Song, Jae. J. 1997. The history of Micronesian possessive classifiers and benefactive marking in Oceanic languages. Oceanic Linguistics 36(1): 29-64.

Sugita, Hiroshi. 1987. A study of Trukese possessive expressions. PhD diss., University of Hawai'i at Manoa.

Wierzbicka, Anna. 2009. All people eat and drink. Does this mean that 'eat' and 'drink' are universal concepts? In The linguistics of eating and drinking, ed. by John Newman, 65-89. Amsterdam/Philadephia: John Benjamins Publishing Company.

Williams, Herbert W. 1971. A Dictionary of the Maori Language. Wellington: A.R. Shearer, Government Printer of New Zealand.

Zubin, David, and Mitsuaki Shimojo. 1993. How "General" are General Classifiers ? With Special Reference to ko and tsu in Japanese. Proceedings of the Nineteenth Annual Meeting of the Berkeley Linguistics / General Session and Parasession on Semantic Typology and Universals 19(1): 490-502. 
TABLE 1. KANAK LANGUAGES AND DATA SOURCES USED IN THIS STUDY

\begin{tabular}{|c|c|c|}
\hline Subgroup & Language $^{\dagger}$ & Source \\
\hline \multirow[t]{8}{*}{ New Caledonia > Mainland > North } & Nyelâyu & Ozanne-Rivierre 1998 \\
\hline & Nêlêmwa & Bril 2000 \\
\hline & Caac & Hollyman (unpublished), Cauchard 2018 \\
\hline & $\begin{array}{l}\text { Hienghène languages: } \\
\text { Jawe, Nemi, Fwâi, Pije }\end{array}$ & Haudricourt and Ozanne-Rivierre 1982 \\
\hline & Pwapwâ, Pwaamei & Ozanne-Rivierre 2007 \\
\hline & $\begin{array}{l}\text { Voh-Koné languages: } \\
\text { Bwatoo } \\
\text { Vamale }\end{array}$ & $\begin{array}{l}\text { Rivierre and Ehrhart } 2006 \\
\text { J. Rohleder (p.c.) }\end{array}$ \\
\hline & Cèmuhî & Rivierre1994 \\
\hline & Paicî & Rivierre 1983 \\
\hline \multirow[t]{6}{*}{ New Caledonia > Mainland > South } & Ajië & Lercari, 2002, Poedi, P. (pers.com.) \\
\hline & Haméa & Moyse-Faurie (own data) \\
\hline & Xârâcùù & Moyse-Faurie and Néchérö-Jorédié 1989 \\
\hline & Tîrî & Osumi 1995 \\
\hline & Drubéa & Shintani and Païta 1990 \\
\hline & Numèè & Rivierre (unpublished) \\
\hline \multirow[t]{3}{*}{ New Caledonia > Loyalty Islands } & Iaai & Ozanne-Rivierre 1984; Dotte 2013 \\
\hline & Drehu & Sam 2009 \\
\hline & Nengone & Bearune, S. (pers. com.) \\
\hline Polynesian outlier & Fagauvea & Hollyman 1987 \\
\hline
\end{tabular}

$\dagger$ Languages in this table and following tables are arranged North to South.

TABLE 2. REFLEXES OF THE POC GENERIC TERM FOR 'EATING'

\begin{tabular}{|c|c|c|c|}
\hline \multicolumn{2}{|l|}{ PMP } & *kaen & 'eat' \\
\hline \multicolumn{2}{|l|}{ POC } & *kani[-] & 'eat (s.t. starchy), eat (in general)' \\
\hline \multicolumn{2}{|l|}{ Proto-New Caledonia } & *kani & \\
\hline \multirow[t]{2}{*}{ Mainland (North) } & $\begin{array}{l}\text { Hienghène languages: } \\
\text { Pwapwâ, Bwatoo }\end{array}$ & cani & 'eat starchy food' \\
\hline & Pwaamei & zani & 'eat starchy food' \\
\hline Mainland (South) & Xârâcùù & kê & 'eat starchy food' \\
\hline \multirow[t]{4}{*}{ Loyalty Islands } & Iaai & han & 'eat (intransitive)' \\
\hline & & an & 'eat (transitive)' \\
\hline & Drehu & xen & 'eat, eat starchy food' \\
\hline & Nengone & kaka(n) & 'eat (generic; less protein)' \\
\hline \multirow{3}{*}{$\begin{array}{l}\text { Proto-Polynesian } \\
\text { Loyalty Islands }\end{array}$} & these & $* \mathrm{kai}^{\dagger}$ & 'eat, food' \\
\hline & Fagauvea & kai & 'eat (intransitive)' \\
\hline & 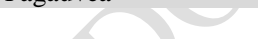 & kaina & 'eat (transitive)' \\
\hline
\end{tabular}

$\dagger$ It is interesting to notice that kaikkaï [kajkaj] is a very common word in the local Caledonian French, meaning 'to eat; food' (Pauleau 1995:93). It comes from a reduplicated form of the Polynesian term. Bislama (the national pidgin language of Vanuatu) has a very similar form for 'food': kakae.

\section{TABLE 3. 'EAT (GENERIC)' IN KANAK LANGUAGES}

\begin{tabular}{ll|ll} 
Mainland languages & & Loyalty Islands languages & \\
Nyelâyu; Caac; Jawe & huu & Iaai & an \\
Nêlêmwa & khuwo & Drehu & xen \\
Nemi; Fwâi; Pije & hwi-aman & Nengone & kaka(n) \\
Pwapwâ; Pwaamei; Vamale & xhwi-aman & & \\
Bwatoo & vwhaxi-aman & & \\
Cèmuhî & wíi-naado & & \\
Paicî & íjá & & \\
Ajië & ara & & \\
Xârâcùù & da & & \\
Tîrî, Haméa & harra & & \\
Drubéa & kèrè-re & & \\
Numèè & kii-rè & & \\
\hline
\end{tabular}


TABLE 4. 'EAT (SUGARCANE)' IN KANAK LANGUAGES

\begin{tabular}{ll|ll} 
Mainland & & Loyalty Islands & \\
Nyelâyu & huur & Iaai & hwii \\
Nêlêmwa & khuri & Drehu & atra \\
Caac & huuxuc & & \\
Jawe; Nemi; Fwâi & huli & & \\
Pije & holi & & \\
Pwapwâ & xhuli & & \\
Pwaamei & huti & & \\
Bwatoo; Vamale & xhuti & & \\
Paicî & wíi & & \\
Ajië & kwârâ & & \\
Tîrî́ Haméa & hwii & & \\
Drubéa & kùu-re & & \\
Numèè & kuu-rè & & \\
\hline
\end{tabular}

TABLE 5. 'EAT (PROTEINS)' IN KANAK LANGUAGES

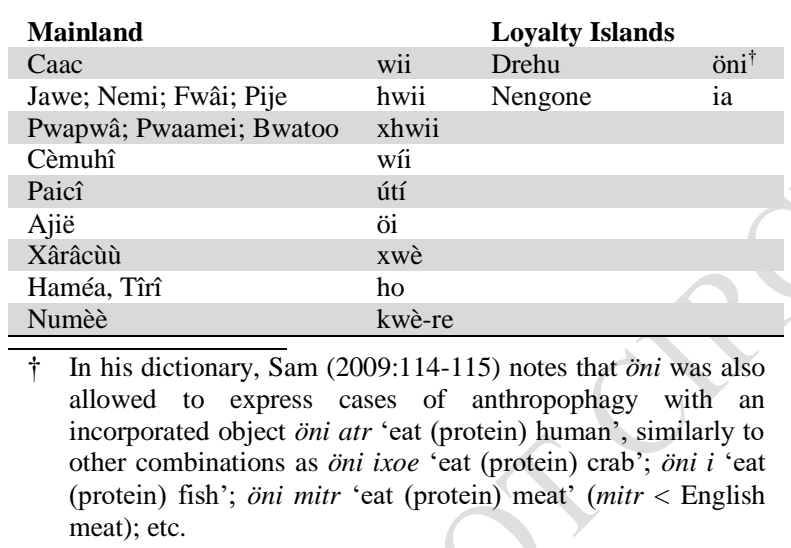

TABLE 6. 'EAT (STARCHY FOOD)' IN KANAK LANGUAGES

\begin{tabular}{ll} 
Mainland & \\
Nêlêmwa & khuxi \\
Caac; Jawe; Nemi; Fwâi; Pije; Pwapwâ & cani \\
Pwaamei & zani \\
\hline Bwatoo; Vamale & xhajake \\
Cèmuhî & éni \\
\hline Ajië & kâi \\
Xârâcùù & kê \\
Haméa, Tîrî & é \\
\hline
\end{tabular}

TABLE 7. 'EAT (CHEWABLE FOOD)' IN KANAK LANGUAGES

\begin{tabular}{ll|ll} 
Mainland & & Loyalty Islands & \\
Caac & maani & Iaai & hicâ \\
Jawe & hwei & Nengone & chaphan \\
Nemi; Fwâi; Pije & hwai & & \\
Pwapwâ & xhwei & & \\
Pwaamei & xhwai & \\
Vamale & fwai & \\
Cèmuhî & pwèi & \\
Paicî & pwé & \\
Ajië & kwârâ & \\
\hline
\end{tabular}

TABLE 8. 'EAT (GREENS)' IN KANAK LANGUAGES

\begin{tabular}{ll} 
Mainland & \\
Nyelâyu & ûûr \\
Nêlêmwa & kûûra/kûûri \\
\hline Caac; Jawe & kuuni \\
\hline Nemi; Fwâi; Pije & kaje \\
Pwapwâ; Pwaamei & kûûni \\
Bwatoo & kûû \\
Vamale & xaje \\
Cèmuhî & anye \\
\hline
\end{tabular}


TABLE 9. 'EAT (RAW FOOD, GREEN FRUITS PROTEINS)' IN KANAK LANGUAGES

\begin{tabular}{ll} 
Mainland & \\
\hline Nyelâyu & thaxilo \\
\hline Nêlêmwa & thaxilolî \\
\hline Drubéa & kwè-bérii-re \\
\hline
\end{tabular}

TABLE 10. 'DRINKING SOMETHING COLD' AND 'DRINKING SOMETHING WARM' IN NORTH MAINLAND KANAK LANGUAGES

\begin{tabular}{llll} 
Subgroup & Language & 'to drink sth cold' & 'to drink sth warm' \\
New Caledonia $>$ Mainland $>$ North & Jawe & knuduk & phelo \\
& Nemi & knuduk & thop, felo \\
& Fwâi & khûdûk & vhelo \\
\hline Pije & khûdûk & vhalo \\
& Pwapwâ & kûduk & thovi \\
& Pwaamei & kûduk & thop \\
& Bwatoo & xudu & traao \\
Vamale & undu & fato \\
\hline
\end{tabular}

TABLE 11. FOOD CATEGORIES DISTINGUISHED BY POSSESSIVE CLASSIFIERS IN KANAK LANGUAGES ${ }^{\dagger}$ sugarcane; greens, leaves, food (generic) juicy food protein starchy food chewable fruits unripe fruits fish/shellfish

\begin{tabular}{|c|c|c|c|c|c|c|c|c|}
\hline & & & & & & & & \\
\hline Nyelâyu & & $x$ & $x$ & $x$ & $x$ & $x$ & & \\
\hline Nêlêmwa & & $x$ & $x$ & $x$ & $x$ & $\times$ & $x$ & \\
\hline Caac & & & $x$ & $x$ & $x$ & & & \\
\hline Jawe; Nemi; Fwâi; Pije & & $x$ & $x$ & $x$ & $x$ & $x$ & & $x$ \\
\hline Pwaamei; Pwapwâ & & $x$ & $x$ & $x$ & $C$ & $x$ & & \\
\hline Bwatoo & & $x$ & $x$ & $x$ & $x$ & $x$ & & \\
\hline Cèmuhî & & $x$ & $x$ & $x$ & $\times$ & $x$ & & \\
\hline Xârâcùù & $x$ & & $x$ & $x$ & $x$ & $x$ & & \\
\hline Tîrî & & & $x$ & $x$ & $x$ & $x$ & & \\
\hline Drubea & $x$ & $x$ & $x$ & $x$ & & & & $x$ \\
\hline Iaai & $x$ & $x$ & & & $x$ & & & \\
\hline
\end{tabular}

$广 \mathrm{x}$ means that a possessive classifier does exist in the language to express the concerned semantic food categories, whereas shaded cell means that there is no possessive classifier attested for the category.

TABLE 12. FWÂI (HIENGHÈNE LANGUAGE, NORTH MAINLAND) POSSESSIVE CLASSIFIERS

Food Possessive Classifiers Corresponding Eating Verbs

\begin{tabular}{|c|c|c|c|c|}
\hline a. & $c a-$ & 'P_CL.STARCHES' & cani & 'eat starchy food (yam, taro, banana, rice)' \\
\hline b. & havie- & 'P_CL.SHELLFISH' & \multirow{2}{*}{ hwii } & \multirow{2}{*}{ 'eat meat, fish, crustacean, coconut, corn...' } \\
\hline c. & hue- & 'P_CL.PROTEIN' & & \\
\hline d. & hule- & 'P_CL.SUGARCANE' & huli & 'eat, to suck sugarcane' \\
\hline e. & hwaa- & 'P_CL.CHEWABLE' & hwai & 'chew barks or magnania' \\
\hline f. & kuu- & 'P_CL.GREENS' & kaje & 'eat cooked leaves, salad, some fruits' \\
\hline
\end{tabular}


TABLE 13. COMPARATIVE LEXICON FOR 'EATING' VERBS IN TWENTY-TWO KANAK LANGUAGES ${ }^{\dagger}$

\begin{tabular}{|c|c|c|c|c|c|c|c|c|c|}
\hline & 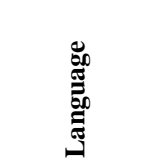 & 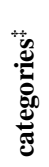 & 营 & 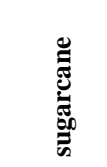 & $\begin{array}{l}\frac{0}{0} \\
\frac{\pi}{\pi} \\
\frac{\pi}{0}\end{array}$ & 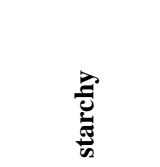 & 葛 & 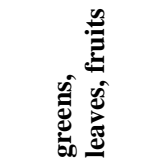 & 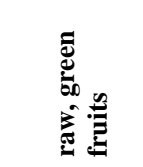 \\
\hline \multirow[t]{12}{*}{$\begin{array}{l}\text { Mainland > } \\
\text { North }\end{array}$} & Nyelâyu & 5 & huu & huur & & \multicolumn{2}{|c|}{$\begin{array}{c}\text { starchy+protein } \\
\text { huc }\end{array}$} & ûûr & thaxilo \\
\hline & Nêlêmwa & 5 & khu-wo, khuxi & khuri & & khuxi, baali $^{\#}$ & & kûûra/kûûri & thaxilolî \\
\hline & Caac & 6 & huu; whic & huuxuc & maani & cani & wii & kuuni & \\
\hline & Jawe & 6 & huu & huli & hwei & cani & hwii & kuuni & \\
\hline & Nemi, Fwâi & 6 & hwi-aman & huli & hwai & cani & hwii & kaje & \\
\hline & Pije & 6 & hwi-aman & holi & hwai & cani & hwii & kaje & \\
\hline & Pwapwâ & 6 & xhwi-aman & xhuli & xhwei & cani & xhwii & kûûni & \\
\hline & Pwaamei & 6 & xhwi-aman & huti & xhwai & zani & xhwii & kûûni & \\
\hline & Bwatoo & 5 & vwhaxi-aman & xhuti & & xhajake & xhwii & kûû & \\
\hline & Vamale & 5 & xhwi-aman & xhuti & fwai & xhajake & & xaje & \\
\hline & Cèmuhî & 5 & wíi-naado & & pwèi & éni & wíi & anye & \\
\hline & Paicî & 4 & íjá & wíi & pwé & & útí & & \\
\hline \multirow{5}{*}{$\begin{array}{l}\text { Mainland > } \\
\text { South }\end{array}$} & Ajië & 5 & ara & wa' & kwârâ & kâi & öi & & \\
\hline & Xârâcùù & 4 & da & \multicolumn{2}{|c|}{$\begin{array}{c}\text { sugarcane+chewable } \\
\text { xwii } \\
\end{array}$} & kê & xwè & & \\
\hline & Haméa,Tîrî & 4 & harra & hwii & & é & 21 & & \\
\hline & Drubéa & 4 & kèrè-re & kùu-re & & & \multicolumn{2}{|c|}{$\begin{array}{c}\text { protein+greens } \\
\text { kwè-re }\end{array}$} & kwè-bérii-re \\
\hline & Numèè & 3 & kii-rè & kuu-rè & & & kwè-re (fish) & & \\
\hline \multirow{4}{*}{$\begin{array}{l}\text { Loyalty } \\
\text { Islands }\end{array}$} & Iaai & 3 & an/han & hwii & hicâ & & & & \\
\hline & Drehu & 3 & xen & atra & & & öni & & \\
\hline & Nengone & 3 & kaka/kakan & & chaphan & & ia/ian & & \\
\hline & 22 & & 22 & 19 & 13 & 15 & 17 & 12 & 3 \\
\hline
\end{tabular}

$\dagger$ Light grey empty cell means that there is no lexicalized specific form attested to render the action of related food consumption. Instead, it is the generic 'eating' verb that applies.

$\ddagger$ We only counted categories that are distinguished by specific verbs (or the generic). A verb that merges two categories of otherwise distinguished categories is not counted.

\# Ba/baali in Nixumwak (Koumac dialect; Bril 2000:95). 